\title{
МІЖНАРОДНІ СТАНДАРТИ ПРАВ ЛЮДИНИ ТА ЇХ ІМПЛЕМЕНТАЦІЯ У ПРОЦЕСІ РЕАЛІЗАЦІЇ ПРАВОЗАХИСНОЇ ФУНКЦІї СУДОВОЇ ВЛАДИ В УКРАЇНІ
}

Чорна С. 3.

У науковій статті здійснено комплексний науково-теоретичний аналіз сутності міжнародно-правових стандартів захисту прав людини в контексті реалізаціі правозахисної функції судової влади в Україні.

Розглядаються міжнародні стандарти захисту прав людини як закріплені в міжнародних документах уніфіковані та загальноприйняті принципи та норми, що закріплюють мінімально необхідний перелік умов, яким повинна відповідати процедура захисту прав людини.

Робиться висновок, що правосуддя виступає основним правозахисним механізмом у державі та може виконувати свою важливу функцію завдяки імплементації загальноприйнятих міжнародних стандартів судового захисту прав людини.

Ключові слова: права людини, міжнародні стандарти, стандарти захисту прав людини, судова влада, право на судовий захист, правосуддя, імплементація, правозахисна функція.

В научной статье осуществлен комплексный научно-теоретический анализ сущности международно-правовых стандартов защиты прав человека в контексте реализации правозащитной функции судебной власти в Украине.

Рассматриваются международные стандарты защиты прав человека как зафиксированные в международных документах унифицированные и общепринятые принципы и нормы, закрепляющие минимально необходимый перечень условий, которым должна соответствовать процедура защиты прав и свобод человека.

Делается вывод, что правосудие выступает основным правозащитным механизмом в государстве, и может выполнять свою важную функцию благодаря имплементации общепринятым международным стандартам судебной защиты прав человека.

Ключевые слова: права человека, международные стандарты, стандарты защиты прав человека, судебная власть, право на судебную защиту, правосудие, имплементация, правозащитная функция.

Chorna S. Z. International human rights standards and their implementation in the process of realization of the function of human rights protection of the judiciary in Ukraine

(c) Чорна С. 3., 2020
The article provides a comprehensive scientific and theoretical analysis of the essence of international legal standards for the protection of human rights in the context of the implementation of human rights function of judiciary in Ukraine.

The author notes that the problem of protection of fundamental human rights goes far beyond the policy of an individual state and requires the formation of international legal standards. It is stated that the standards of human rights protection are enshrined in a number of important international legal documents that most fully reflect the achievements of mankind in this area and establish universally recognized principles of fundamental human rights and interests, beyond which no state can go.

International standards of human rights protection are considered as unified and generally accepted principles and norms declared in international documents, which establish the minimum necessary list of conditions that human rights protection procedure must meet.

The basic standards of protection of human rights are enshrined in the Constitution of Ukraine in the relevant provisions on protection of human and civil rights and freedoms by the court, administration of justice exclusively by courts, inadmissibility of delegation and appropriation of this power by other bodies or officials and others.

It is stated that in a democratic state, judiciary is responsible for the administration of justice. It plays a leading role in the protection of fundamental human rights and freedoms, because it is a guarantee and at the same time a mechanism for the protection of all other institutions. The task of the state is to provide everyone who has applied for judicial protection with the maximum guarantees concerning the administration of justice. These guarantees are enshrined in the form of international legal standards for the protection of human rights.

Judiciary is recognized as one of the most effective means of protecting human rights and freedoms, the main task of which is to restore the violated right. It is concluded that justice is the main human rights mechanism in the state, and can perform its important function through the implementation of generally accepted international human rights standards.

Key words: human rights, international standards, human rights standards, judiciary, right to judicial protection, implementation, justice, human rights protection function. 
Постановка проблеми та іï актуальність. Реформування правової системи держави потребує врахування міжнародних стандартів, доктринальних положень, правових цінностей та кращого практичного досвіду їх утілення сучасних розвинутих зарубіжних держав з усталеними демократичними традиціями. Розпочата у 2014 році, судово-правова реформа продовжується й сьогодні, та має на меті вдосконалення судівництва для утвердження справедливого суду в Україні, відповідно до загальноприйнятих міжнародних i, зокрема, європейських принципів і норм. Їх імплементація $\epsilon$ важливою передумовою для інтеграції нашої держави в європейський простір, а також для набуття Україною необхідних ознак правової держави, серед яких пріоритетними визнається тріада: підпорядкування державної влади праву; визнання державою людини, іï прав і свобод найвищою цінністю; незалежна та ефективно функціонуюча судова влада.

Аналіз останніх досліджень і публікацій. На сьогоднішньому етапі розвитку правової науки проблематикою міжнародно-правового регулювання стандартів захисту прав і свобод людини займалося чимало фахівців, які $\epsilon$ представниками загальної теорії права, конституційного, адміністративного, інших галузей права, а також практикуючих юристів.

Зокрема, підґрунтя дослідження окремих аспектів зазначеного питання становлять праці українських і зарубіжних учених: В.Б. Авер'янова, М.М. Антонович, О.М. Бандурки, Є.В. Білозьорова, М.В. Баглая, І.Л. Бородіна, М.Т. Гаврильців, С.П. Головатого, І.П. Голосніченко, Р.А. Калюжного, В.В. Костицького, А.М. Колодія, Л.С. Криворучко, В.Я. Крижановського, Р.А. Мюллерсона, А.Ю. Олійника, П.М. Рабіновича, Н.М. Раданович, Ю.М. Тодики, О.Ф. Фрицького, Ю.С. Шемшученка, І.А. Шуміло та інших.

Проте, на нашу думку, у вітчизняній юриспруденції бракує довершеної цілісної концепції дослідження імплементації міжнародних стандартів захисту прав і свобод людини у процесі здійснення правозахисної функції судової влади в Україні.

Метою статті $\epsilon$ комплексний науково-теоретичний аналіз сутності міжнародно-правових стандартів захисту прав і свобод людини в контексті реалізації правозахисної функції судової влади в Україні.

Виклад основного матеріалу. Забезпечення та гарантування прав і свобод людини $\epsilon$ основним обов'язком правової держави, а судова влада виступає основним правовим засобом їх ефек- тивного захисту прав людини. Саме це орієнтує державну владу на виконання тієї функції, яка, власне, й зумовлює виникнення самої держави та $\epsilon$ основою суспільної злагоди. Адже, як задекларовано в Конституції України, «Права і свободи людини та їх гарантії визначають зміст і спрямованість діяльності держави. Держава відповідає перед людиною за свою діяльність. Утвердження й забезпечення прав і свобод людини $\epsilon$ головним обов'язком держави» (ч. 2 ст. 3); «Права і свободи людини і громадянина захищаються судом» (ч. 1 ст. 55) [1].

Крім того, відповідно до ч. 1 ст. 9 Конституції України, чинні міжнародні договори, згода на обов'язковість яких надана Верховною Радою України, $\epsilon$ частиною національного законодавства України. Таким чином, закріплення права на судовий захист у Конституції України $\epsilon$ результатом імплементації міжнародно-правових норм, які проголошені в міжнародних актах [1].

В умовах сучасного цивілізаційного розвитку проблема захисту основних прав і свобод людини виходить далеко за межі політики окремої національної держави. Тому виникає необхідність формування наднаціональних міжнародно-правових стандартів, яким має відповідати процедура правозахисту як у середині країни, так і поза ії межами.

У процесі формування міжнародно-правових норм у сфері прав людини сформувалась стійка система міжнародного захисту прав людини на основі всесторонньої співпраці між державами. Цей процес бере свій початок після прийняття у 1945 р. Статуту ООН, Преамбула якого закріплює положення що народи Об'єднаних Націй «сповнені рішучості <...> знову утвердити віру в основні права людини, у гідність і цінність людської особистості, в рівноправність чоловіків та жінок і в рівність прав більших та малих націй» [2].

Окрім того, Статут ООН у п. 3 ст. 1 однією із цілей діяльності Організації зазначає: «Здійснювати міжнародне співробітництво у сфері розв'язання міжнародних проблем економічного, соціального, культурного та гуманітарного характеру й у заохоченні та розвитку поваги до прав людини й основних свобод для всіх, без розрізнення раси, статі, мови та релігії [2].

Генеральною Асамблеєю ООН у 2012 р. було ухвалено Декларацію «Верховенство права на національному та міжнародному рівнях», в якій було підкреслено позитивний унесок Генеральної Асамблеї ООН як основного дорадчого і представницького органу Організації Об'єднаних Націй 
для верховенства права в усіх аспектах «шляхом розробки політики та встановлення стандартів» (п. 27) [3].

Отож, як зауважив провідний український фахівець у сфері прав людини П.М. Рабінович, «<...> не $\epsilon$ випадковим, що нині майже в усіх “праволюдинних" публікаціях - наукових, навчальних, публіцистичних, просвітницьких - ідеться про ті чи інші “стандарти” прав людини» [4, с. 19].

Термін «стандарт» (англ. standard - норма, зразок, мірило) в довідкових джерелах тлумачиться як «1) зразок, еталон, модель, які стають мірилом для інших подібних об'єктів; 2) нормативно-технічний документ, що встановлює одиниці величин, терміни та їх визначення, вимоги до продукції й виробничих процесів, безпеки праці тощо)» [5, с. 642].

Інколи слово «стандарт» використовують і в негативному розумінні - як певну шаблонність, трафаретність, відсутність креативності чи оригінальності тощо.

3 огляду на це стандартний - той, що відповідає стандарту, задовольняючи його вимоги, типовий, еталонний для предметів і явищ.

У нормативно-правовому розумінні стандарти відіграють роль певної відповідності, еталонності правил поведінки, що не передбачає диспозитивності (альтернативності вибору) у правовому регулюванні діяльності учасників суспільних відносин.

Зі свого боку, міжнародно-правовий стандарт містить відображення єдності (уніфікованості) в ньому правил і вимог для всіх без винятку держав-учасниць певного міжнародного зобов'язання (конвенції, договору, пакту) й виконує роль орієнтиру, забезпечуючи однотипне виконання однорідних процедур у межах конкретного стандарту.

С.А. Голубок, досліджуючи категорію «міжнародний стандарт», стверджує, що деякі міжнародно-правові акти застосовують термін «стандарт» для «уніфікованих умов, що $€$ мінімально необхідними для держав-учасниць, що представляють собою мінімально допустимий консенсус» [6, с. 113].

Здебільшого стандарти захисту прав і свобод людини закріплені в низці важливих міжнародно-правових документів, що найповніше відображають надбання людства в зазначеній сфері та встановлюють загальновизнані принципи основоположних прав та інтересів людини, за яку жодна держава не може виходити.

Загальноприйняті загальносвітові стандарти захисту прав людини закріплені в Міжнародному біллі про права людини, до якого належать:
Загальна декларація прав людини 1948 р.; Міжнародний пакт про громадянські та політичні права і Факультативні протоколи до нього1966 р.; Міжнародний пакт про економічні, соціальні та культурні права 1966 р.; Міжнародна конвенція про ліквідацію всіх форм расової дискримінації 1966 р.; Конвенція про ліквідацію всіх форм дискримінації щодо жінок 1979 р.; Конвенція проти катувань та інших жорстоких, нелюдських або таких, що принижують гідність, видів поводження й покарання 1984 р.; Конвенція про права дитини 1989 р. тощо. На регіональному рівні надзвичайно важливе значення у сфері захисту прав людини має Європейська конвенція про захист прав людини та основних свобод 1950 р. [7]

У зв'язку із цим П.М. Рабінович доречно зауважив, що не випадково щодо цих міжнародних договорів висловлювалась думка про те, що правильніше говорити не про права і свободи, закріплювані у них, а, власне, про міжнародні стандарти в галузі прав людини, оскільки термін «стандарти» найбільш точно відображає роль указаних документів. Тому переважно поняття стандартів прав людини пов'язують саме з міжнародно-правовими актами, які найповніше відображають надбання людства у цій сфері [4, с. 19].

Для кращого розуміння правової природи та сутності міжнародних стандартів захисту прав людини надзвичайно важливу роль відіграло прийняття в 1966 р. Резолюції Генеральної Асамблеї ООН «Установлення міжнародних стандартів у сфері прав людини», в якій було викладено керівні принципи, котрі повинні враховуватись під час розробки міжнародних документів у зазначеній сфері, зокрема, вони повинні: «а) узгоджуватись із чинним зводом міжнародно-правових норм у сфері прав людини; b) мати фундаментальний характер і ґрунтуватись на притаманних людській особистості гідності та цінності; с) бути достатньо чіткими, щоб слугувати джерелом прав і обов'язків, які піддаються визначенню й здійсненню; d) передбачати, коли це доречно, реалістичний та ефективний механізм здійснення, включно із системами подання доповідей; е) користуватись усесторонньою міжнародною підтримкою» [8].

Таким чином, узагальнивши всі властивості міжнародних стандартів у сфері захисту прав людини, а також вимоги, котрі ставляться до них, можна сформулювати таке визначення: міжнародних стандарти захисту прав людини - це закріплені в міжнародних документах уніфіковані та загальноприйняті принципи та норми, які закріплюють мінімально необхідний перелік умов, 
яким повинна відповідати процедура захисту прав і свобод людини і які $\epsilon$ обов'язковими для держав-учасниць певного міжнародного зобов'язання (конвенції, договору, пакту), за порушення чи невиконання котрих передбачені санкції правового чи юридичного характеру.

Реальна участь суду у здійсненні захисту прав людини є однією з основних ознак правової державності. Всезагальний характер доступності правосуддя підкреслюється в низці найважливіших міжнародно-правових документів. Так, ч. 1 ст. 6 Європейської конвенції про захист прав людини 1950 р. передбачено, що кожен має право на справедливий і публічний розгляд його справи впродовж розумного строку незалежним і безстороннім судом, установленим законом, який вирішить спір щодо прав та обов'язків цивільного характеру або встановить обґрунтованість будь-якого висунутого проти нього кримінального обвинувачення [7].

Зважаючи на те, що право на судовий захист уходить до переліку прав, що захищаються Конвенцією, доцільно виокремити ті його стандарти, які $€$ обов'язковими в сенсі практики Європейського суду із прав людини. Так, у вже згаданій ст. 6 Конвенції закріплене право на справедливий суд. Зокрема у ч. 1 ст. 6 зазначено, що кожен має право на справедливий і публічний розгляд його справи впродовж розумного строку незалежним та безстороннім судом, установленим законом, який вирішить спір щодо його прав та обов'язків цивільного характеру або встановить обґрунтованість будь-якого висунутого проти нього кримінального обвинувачення.

Судове рішення проголошується публічно, але преса й публіка можуть бути не допущені в зал засідань протягом усього судового розгляду або його частини в інтересах моралі, громадського порядку чи національної безпеки в демократичному суспільстві, якщо того вимагають інтереси неповнолітніх або захист приватного життя сторін або - тією мірою, що визнана судом суворо необхідною, - якщо за особливих обставин публічність розгляду може зашкодити інтересам правосуддя.

Зважаючи на конструкції ч. 1 ст. 6 Конвенції, можна стверджувати, що в ній закріплені такі елементи права на судовий захист: а) право на розгляд справи; б) право на справедливість судового розгляду; в) право на публічність розгляду справи та проголошення рішення; г) право на розумний строк розгляду справи; д) право на розгляд справи судом, встановленим законом; е) право на незалежність і безсторонність суду [7].
Практика Європейського суду із прав людини показує, що якщо в особи немає права на доступ до суду, тоді право на справедливий судовий розгляд $є$ безглуздим. Таким чином, право на доступ до правосуддя $\epsilon$ первинним по відношенню до права на справедливий судовий розгляд.

Із врахуванням положень статей 6 та $13 \mathrm{Koн-}$ венції система стандартів адміністративного процесу може мати такі елементи: 1) право на доступ до суду; 2) право на справедливий судовий процес, що містить такі організаційні та процесуальні гарантії: розгляд справи судом, створеним на підставі закону; незалежність та неупередженість суду; публічний розгляд справи та проголошення рішення суду; справедливий судовий розгляд; розгляд справи впродовж розумного строку; 3) ефективність судового контролю за актами та діями (чи бездіяльністю) органів публічної влади та дієвість судового рішення.

Отже, основні принципи судового процесу, закріпленні в ч. 1 ст. 6 Конвенції, мають бути враховані національним законодавством та судовою практикою, оскільки вони забезпечують захист прав особи в судовому процесі та впливають на його ефективність.

Необхідно констатувати, що на сьогодні міжнародні стандарти у сфері захисту прав людини знайшли свій відбиток в окремих положеннях чинного законодавства. Ефективний захист прав і свобод людини і громадянина в межах здійснення правозахисної діяльності забезпечують суди загальної юрисдикції, які вирішують переважну більшість проблем, пов'язаних із порушенням прав та свобод людини і громадянина.

Основні стандарти захисту прав людини закріплені в Основному Законі України у відповідних положеннях про захист прав та свобод людини i громадянина судом, здійсненням правосуддя виключно судами, недопустимості як делегування, так і привласнення цього повноваження судів іншими органами чи посадовими особами, поширенням юрисдикції судів на будь-який юридичний спір та будь-яке кримінальне обвинувачення. Також надзвичайно ефективною в механізмі судового захисту прав людини $є$ можливість захисту своїх прав у міжнародних судових установах чи відповідних органах міжнародних організацій, членом або учасником яких $\epsilon$ Україна (статті 55, 124 Конституції України [1]).

Серед інститутів демократичної держави судова влада, на яку покладається здійснення правосуддя, відіграє провідну роль у сфері захисту основних прав і свобод людини, адже саме 
вона виступає гарантією й водночас механізмом захисту всіх інших інститутів. У зв'язку з цим завдання держави $\epsilon$ забезпечення кожному, хто звернувся за судовим захистом, максимуму гарантій, що стосуються здійснення правосуддя. Перелік цих гарантій закріплений у вигляді міжнародно-правових стандартів захисту прав людини.

Таким чином, судова влада визнається одним із найефективніших засобів захисту прав і свобод людини, основне завдання якої - відновлення порушеного права. Відповідно, судова форма захисту забезпечує максимум процесуальних гарантій людині, яка звертається за захистом, а тому є вищою формою такого захисту.

Правосуддя як основний правозахисний механізм у державі може виконувати свою важливу функцію саме завдяки імплементації загальноприйнятим міжнародним стандарти прав людини. Такі стандарти випливають із того, що захист прав і свобод кожної людини в судовому порядку гарантується. Здійснюється судовий захист на основі чітко визначених процесуальним законом процедур, завершується винесенням правосудного рішення, що є обов'язковим для виконання та забезпечить відновлення порушеного права. Право на судовий захист - також обов'язковий стандарт захисту прав і свобод людини, адже без судового механізму захист усіх інших прав був би неможливим.

Як і всі інші права та свободи, визнані на міжнародному рівні, право на справедливий суд повинна забезпечити держава, воно $\epsilon$ абсолютним і не може бути ні обмеженим, ані відчуженим (ч. 2 ст. 64 Конституції України) [1].

Висновки. Отже, проблема захисту основних прав і свобод людини виходить далеко за межі політики окремої національної держави та потребує формування міжнародно-правових стандартів, яким має відповідати процедура правозахисту як у середині країни, так і поза ії межами. Стандарти захисту прав людини закріплені в низці важливих міжнародно-правових документів, що найповніше відображають надбання людства в зазначеній сфері та встановлюють загальновизнані принципи основоположних прав та інтересів людини, за яку жодна держава не може виходити.

Під міжнародними стандартами захисту прав людини запропоновано розуміти закріплені в міжнародних документах уніфіковані та загальноприйняті принципи та норми, які закріплюють мінімально необхідний перелік умов, яким повинна відповідати процедура захисту прав і свобод людини, і котрі $є$ обов' язковими для держав-учасниць певного міжнародного зобов'язання (конвенції, договору, пакту), за порушення чи невиконання яких передбачені санкції правового чи юридичного характеру.

Серед інститутів демократичної держави судова влада, на яку покладається здійснення правосуддя, відіграє провідну роль у сфері захисту основних прав і свобод людини, адже саме вона виступає гарантією й водночас механізмом захисту всіх інших інститутів. У зв'язку із цим завдання держави - забезпечення кожному, хто звернувся за судовим захистом, максимуму гарантій щодо здійснення правосуддя. Правосуддя виступає основним правозахисним механізмом у державі та може виконувати свою важливу функцію завдяки імплементації загальноприйнятих міжнародних стандартів прав людини.

\section{Література}

1. Конституція України: прийнята на п'ятій сесії Верховної Ради України 28.06.1996. URL: http: / /zakon5.rada.gov.ua/laws/show/254к/96-вр.

2. Статут ООН від 26 червня 1945 p. URL: https: //zakon.rada.gov.ua/laws/show/995_010\#Text.

3. Верховенство права на національному та міжнародному рівнях: Декларація Генеральної Асамблеї ООН, Прийнята резолюцією 67/1 Генеральної Асамблеї ООН 24 вересня 2012 р. URL: https: / / www.un.org/ru/documents/decl_conv/ declarations/ruleoflaw2012.shtml

4. Рабінович П.М. Міжнародні стандарти прав людини: властивості, загальне поняття, класифікація. Вісник Національної академії правових наук України. 2016 № 1(84). С. 19-29.

5. Сучасний словник іншомовних слів: близько 20 тис. слів і словосполучень / уклали: О.І. Скопненко, Т.В. Цимбалюк. Київ : Довіра, 2006. 789 с.

6. Голубок С.А. Международно-правовые стандарты права на судебную защиту. Правоведение. 2007. № 1. С. 112-124.

7. Конвенція про захист прав людини і основоположних свобод від 4 листопада 1950 p. URL: https://zakon.rada.gov.ua/laws/show/995_004\#Text.

8. Встановлення міжнародних стандартів у сфері прав людини: Резолюція Генеральної Асамблеї ООН 41/120 від 4 грудня 1966 р. URL: http: / / daccessdds-ny.un.org/ doc/RESOLUTION/GEN/ NR0/496/28/ IMG/NR049628.pdf?OpenElement.

Чорна С. 3., суддя

Сихівського районного суду міста Львова 